слідженні інтерпретується як сукупність організацій різної галузевої приналежності та організаційно-правових форм, владних і громадських структур, що визначають та забезпечують реалізацію освітніх програм певного рівня чи спрямованості, а також умови для стратегічного інноваційного розвитку системи освіти в сучасних ринкових умовах із залученням специфічних форм організації інноваційної діяльності, які зарекомендували себе в процесі реалізації широкомасштабних експериментів, пілотних проектів з окремих напрямків модернізації. Описано можливості впровадження освітніх кластерів на різних управлінських рівнях. Запропоновано структуру освітнього кластеру, а також конкретні етапи його впровадження. Обгрунтовано результати ефективної реалізації освітніх кластерів у напрямку стратегічного розвитку вітчизняної системи освіти. Освітній кластер може виступати інструментом державної політики України в сфері завоювання провідних місць на світових ринках освітніх послуг. Формування та розвиток ефективних освітніх кластерів сприятиме: прискоренню передачі (обміну) інформації і встановлення контактів, реакції на зміни в зовнішньому середовищі; спрощенню доступу до нових технологій; спільному використанню знань $\mathrm{i}$ основних фондів; прискоренню і підвищенню ефективності процесів навчання та професійної підготовки кадрів за рахунок концентрації, фізичних контактів фахівців високого рівня, корегування навчальних планів закладів освіти, спільної організації програм перепідготовки та підвищення кваліфікації кадрів, стажувань; зниженню трансакційних витрат у різних областях; збільшенню інвестицій завдяки досягненню стійких конкурентних переваг.

Ключові слова: освітній кластер, управління освітою, партнерство, інновації, ефективність кластерів, стратегічний розвиток освіти.

Submitted on April, 14, 2017

UDC:373.5.091.33:62

DOI: https://doi.org/10.24195/2414-4665-2017-5-12

Liudmyla Chystiakova,

PhD (Candidate of Pedagogical Sciences), associate professor, Department of Theory and Methodology of Technological Education, Labour Protection and Health, Volodymyr Vynnychenko Central Ukrainian State Pedagogical University,

1, Shevchenko Str., Kropyvnytskyi, Ukraine

\title{
THE PROJECT METHOD AT DESIGN AND TECHNOLOGY LESSONS IN TERMS OF REFORMING THE NEW UKRAINIAN SCHOOL
}

According to a new program for general secondary education institutions approved by the Ministry of Education and Science of Ukraine, Design and Technology Lessons are considered as a leading tool of the development of students' ability for self-studying, mastering the tools of modern technologies, building the cognitive process and carrying out their plans practically. Labour training provides the formation, purposeful manifestation and development of students' skills and cultivates their project and technological competency as a component of key and subject competencies. The aim of the paper is to provide explanation of the efficiency of the project method and the necessity of its implementation during academic and labour training at Design and Technology lessons. The survey results of Design and Technology teachers from different regions of Kirovohrad region have shown that most of them do not have profound knowledge of using the project method in their teaching practice. They are not quite aware of the requirements of projects and main tasks of the project-based teaching technology, that is why the study is considered to be relevant for Ukrainian education system. The use of the project method in the art and labour creativity will enhance a holistic development of students' personalities, their preparation for the subjecttransforming activity. It also helps students to satisfy their own interests, needs; cultivate their independence, develop their communicative skills. The purpose of an academic project is to create such educational conditions under which students will gain the experience in a project activity. The project based technology covers the following issues: didactic, educational, developmental. Some recommendations for teachers working with this technology have been also presented in the paper.

Keywords: the project method, labour training, the project based technology, a project and technological competency, a creative activity

\section{Introduction}

Labour training classes which students attend at general secondary education institutions are aimed at shaping a new kind of personality who knows how to use methods of a creative search, manifests a creative initiative, is aware of the priority of choosing the right tools in order to achieve the ultimate goal, possesses technological knowledge and has a vision of creative orientation of his/her activity. Labour training should be intellectually coloured. It should provide holistic and all-round education helping every student to develop physically, intellectually, socially and spiritually by implementing a person- 
centred approach in cultivating students' creative skills at these lessons.

According to a new program for general secondary education institutions "Labour Training for Pupils aged from 5 to 9" approved by the Order of Ministry of Education and Science of Ukraine (No.804 dated June, 7, 2017) students can be developed in the process of project activity at Design and Technology Lessons, which is considered as a leading tool of the development of their ability for self-studying, mastering the tools of modern technologies, building the cognitive process and carrying out their plans practically [6].

The aim of Design and Technology lessons in the previous curriculum which was approved in 2015, was to realise the principle of variability and was based on a practical design and technology activity. A new curriculum is focused on forming students' key and subject competences which can make the process of labour training more open to students' life needs, interests and aptitudes.

Labour training provides the formation, purposeful manifestation and development of students' skills and cultivates their project and technological competency as a component of key and subject competencies.

The project and technological competency is a student's ability to utilize knowledge, skills and abilities to manufacture a product or provide a service while doing a project and technological activity starting from creating an idea and up to its realising using the chosen technology.

A student can obtain this competency only while building his/her subjective (active and interactive) outlook in the educational process and when he/she together with a teacher and classmates participates in designing his/her own educational focus [ibid]. The leading tool of such a student's activity is the project method.

The aim of this article is to provide explanation of the efficiency of the project method and the necessity of its implementation during academic and labour training at Design and Technology lessons. This study is urgent due to the adoption of a new curriculum of Design and Technology in Ukraine. The implementation of new principles will ease the process of learning and processing new material by students.

We can find theoretical fundamentals of implementing the project based technology in the researches of American scientists, such as J. Dewey, W. Kilpatrick, E. Collings at the beginning of the $20^{\text {th }}$ century; the technology of realising project and technological methods at Design and Technology lessons in the works by N. Borynets, R. Hurevych, O. Kobernyk, M. Kortsia, H. Levchenko, L. Orshanskyi, A. Tereshchuk, V. Sydorenko, S. Yashchuk and others.

Teachers and practitioners such as S. Lisova, O. Medvid, Yu. Palii, T. Popova, Yu. Pryhodko, Ye. Umanets, I. Hodzytska suggest recommendations of using the project method in their methodological developments.

\section{Research methods}

The following research methods were used in the study: scientific literature and curricula review, theoretical analysis, comparison, classification; interviewing and questioning.

Having analysed the experience of teachers of Design and Technology at schools of different regions of Kirovohrad region we can state that most of them do not have profound knowledge of using the project method in their teaching practice. They use academic, educational and developing potential of the project activity intuitively and unreasonably. They are not quite aware of the requirements of projects and main tasks of the project-based teaching technology.

In order to find out the extent of the readiness of teachers and practitioners to organise and perform a project and a technological activity at school we offered the participants of the qualification upgrading courses (school teaching staff of Kirovohrad region having more than five years' teaching experience) to take part in a survey. 117 teachers $(43 \%$ - teachers of technical labour training and $57 \%$ - teachers of servicing labour training) were asked to answer the questions of the questionnaire and to describe this area of their work informally.

The survey outcomes have shown that $54 \%$ of the teachers use the project method to complete variable modules, $37 \%$ of the respondents actively use this method and $9 \%$ of them do not use it at all. Though all the respondents understand the importance of implementing the method of projects in the educational process and emphasise the necessity of improving their methodological knowledge and enhancing their practical skills in project and technological activity. The participants were offered some criteria and indicators to evaluate their readiness to organise a project and technological activity in teaching. $11 \%$ of the respondents assessed their level of readiness to organise a project and technological activity in teaching as low, $32 \%$ of the teachers assessed it as satisfactory and the rest of teachers considered their level to be high.

The conducted research resulted in understanding the necessity of highlighting this problem in scientific and methodological literature in order to implement the project method in teaching and learning at Design and Technology Lessons in an efficient way.

\section{Discussion}

A project and technological approach is considered in contemporary pedagogical literature to be a personcentred pedagogical technology based on a person and activity approach. In this approach, the learning process is focused on formulating and solving cognitive and communicative and research problems by the students themselves. The process of organisation of learning is designed in such a way that it takes into account every student's abilities and talents, creates favourable conditions for the development of his/her personality, creative thinking, self-sufficiency, and persistency. Here the inner world, consciousness, goals, values, spiritual needs which are formed in school years should also be considered. 
The use of the project method in the art and labour creativity will enhance a holistic development of students' personalities, their preparation for the subjecttransforming activity. It also helps students to satisfy their own interests, needs; cultivate their independence, develop their communicative skills.

Contemporary researchers V. Berbets, O. Kobernyk, H. Kondratiuk, V. Sydorenko, V. Symonenko, S. Yashchuk and others state that the project technology as a model of a person-centred subject-transforming activity is aimed at developing students' creative potential and cognitive skills, providing them with profound knowledge and ways of logical thinking.

The purpose of an academic project is to create such educational conditions under which students will gain the experience in a project activity. Here a teacher should perform the following tasks:

to transfer the knowledge to students and to teach them to integrate, utilise it while obtaining new knowledge in order to perform cognitive and practical tasks;

to teach students to process the information properly that is to be able to collect the necessary information, analyse it, formulate the hypothesis, summarise and compare, find different ways and options to perform tasks rationally and to make valid conclusions;

- to develop communicative skills to be able to work in a team, to cultivate abilities to work in different social groups, spheres, situations, play different social roles such as a leader, a doer, a facilitator;

- to teach students how to develop their own personal morality, intelligence, culture.

Thus, the project based technology covers the following issues: didactic (it provides students with theoretical and applied knowledge, enhances their motivation in obtaining additional knowledge; informs them about methods of scientific cognition and ways of interpreting the outcomes), educational (it facilitates the development of universal values, leadership skills, independence and responsibility), developmental (it improves students' research and creative abilities, enhances the ability to reproduce and utilise the knowledge and communicative skills in different situations, to develop the ability to feel at ease in an information space) [7].

The project based technology involves the whole system of didactic means (content, methods, tools) which stimulates students' interest in the issue and encourages them to use the obtained knowledge in practice and adapts an educational process to structural and organisational requirements of an academic design aiming at solving one or some problems which imply that some knowledge has been already gained. Designing is a kind of anticipatory reproduction of reality, the process of creating a prototype of an anticipatory object, phenomenon or process using specific methods, in particular, the project method. We consider the project method to be a didactic category which identifies a system of tools and ways to obtain specific practical or theoretical knowledge, skills for some specific activity.

The project method as an educational technology appeared in the $20 \mathrm{~s}$ of the $20^{\text {th }}$ century in the USA [1]. It was called the problem method. The characteristic feature of this method was a student's individual work according to the plan which was made together with a teacher.

Dr. Michael Knoll performed a profound research dealing with the origin and development of a project activity, main models and modern interpretation of the project method in practice [8]. Robert T. Howell made a great contribution of the use of the project method to technological education. He defines the project method as an efficient means of enhancing students' learning, studies the project method from the historical point of view, its use in present education and perspectives for the further development of the project technology in technological education [9].

The principle of the project method is to stimulate person's interest in some problems that is to encourage a student to obtain some knowledge and to use it in practice by doing some project activity aimed at solving one or a number of problems. It means from theory to practice that is to be able to combine academic and pragmatic knowledge while setting up the appropriate balance at each level of learning.

Today the notion of project has entered different areas of the society, in particular the domain of humanities. Different projects became popular such as ecological, economic, political, sport, entertaining ones. Thus, the notion of project has gone beyond general technical understanding. It can be interpreted as a series of actions which is organised by a teacher in a special way and done by a student individually and which results in creating a creative product.

O. Kobernyk interprets the project method as a system of learning due to which students gain knowledge while planning and doing tasks in the form of projects which are gradually getting more complicated [3]. Moreover, in terms of the form of the learning activities organisation the project method is considered by scientists as a process during which students set up some practical tasks (projects) by themselves, gain knowledge and cultivate their skills while doing them (N. Nychkalo); as a comprehensive work of all educational process participants aiming to get an educational product for some period of time (A. Hutorskyi); as a process during which students obtain knowledge and master skills while planning and doing practical tasks (projects) (K. Bahanov).

The project based technology is primarily based on student's individual, active cognitive and practical work (group, pair, individual) starting from choosing a topic of the project and up to getting an ultimate result. Students can choose the object of the project individually according to their capacities, develop a design or make a product, prove the validity of the product in real life. Doing this kind of project activity, students obtain knowledge and cultivate skills gaining their labour experience which 
develops and becomes a part of their holistic development.

The basic principle of the project method is the development of cognitive, creative skills and abilities which demands that students will construct their knowledge and focus in an information space individually.

I. Serheev believes the project method involves the following issues: problem - projecting (planning) searching for information - product - presentation - portfolio (which is a file which involves all materials of the project including drafts, schedules, reports, etc.). The goal of a portfolio is to present everything a student has performed (doing his/her best) during the project [5].

O. Kobernyk and S. Yashchuk state that a teacher in the process of project and technological activity becomes a source of information, an organiser of students' individual creative subject-transforming activity, a competent consultant and facilitator whose duty is to teach students to obtain the knowledge individually, use research methods. Students highly appreciate the teachers who are competent in their areas, who can attract students by their skilfulness and proficiency [2]. All abilities can be combined in an integral notion of a professional competency that is the ability, the experience to work and create a quality product, the process of finding new solutions, improving the technology of a labour process.

A teacher faces the challenge to organise, navigate and regulate students' project activity skilfully. This is the teacher who coordinates students' project activity work, direct it at obtaining knowledge, makes the process cognitive and creative, presents its social and creative meaning, teaches students to analyse the information, facilitates them to seek for effective ways of achieving goals, consults students, teaches students how to use new methods of work, controls and evaluates student's achievements, organises students' self-analysis and feedback.

A future teacher of Design and Technology needs specific training which includes the following aspects:

a) learning theoretical and methodological fundamentals of students' creative project activity;

b) developing his/her own project and technological skills and abilities;

c) developing emotional axiological attitude towards the implementation of the project technology as in so outside the classroom (a technological outlook, project and technological thinking, creativity, positive psychological attitude, the presence of technological abilities, etc.);

d) mastering teaching techniques (traditional and innovative teaching methods) and managing the process of project activity.

Taking theoretical principles of scientific researches as a basis we can identify the following types of projects which are used in art and labour activity at Design and Technology lessons:

- according to the nature of students' activity: creative, gaming, informative, and practical;
- by the number of participants: individual, pair, group, team;

- by duration: short-term (some lessons), of average duration (from one week till one month), long-term (some months).

Basing on the teaching practice we can state that mixed types of projects are used at Design and Technology lessons though the most popular projects are creative ones. Their characteristic feature is a creative focus, the presence of a problem situation which needs solving. This is a kind of academic and labour task the result of which is joint creation of art works, everyday products, entertainment events, etc. It is necessary to take into account the level of knowledge and abilities which students possess so that they should be able to transform and focus on a specific object (project). We also recommend taking into consideration the possibility of implementing crosscurriculum, consistency in learning.

When choosing a topic of a project in art and labour activity at Design and Technology lessons it is necessary to take into account an educational situation as well as students' interests, talents, age, individual peculiarities. School facilities should meet the demands of a curriculum which, in its turn, should present a list of project objects.

Despite the type of a project a student as its performer and a teacher should follow such recommendations:

- a project object is chosen according to the nature of art and technological activity;

- project objects should be socially or personally useful and present a subjective (sometimes objective) novelty;

the process of creating a project object should raise students' interest to this kind of art and technological activity, be technologically inviting, original in its design solution;

- the task of a project object should be complicated due to students' mental and physiological peculiarities;

- a product which a student is creating should partly reproduce the labour methods and operations mastered earlier in order to develop and consolidate them.

It is necessary to note that students' work may either follow or go beyond the topic of a project. It is evident that apart from obtaining theoretical knowledge and practical skills and abilities of labour training such organisation of an academic process can help to solve the problem of synthesising the knowledge from different domains of science and handicrafts.

Despite the type and topic, a project should conform to the general structure of projects. The psychopedagogical and methodological literature review in this area has shown that G. Altshuller, L. Iliaieva and V. Symonenko identify the following three steps of art and technological activity: organisational and preparatory, technological and final. V. Berbets, O. Kobernyk, V. Sydorenko and S. Yashchuk offer the following four stages of doing a project: organisational and preparatory, designing, technological and final. In our point of view, these interconnected steps reveal the succession of devel- 
oping and doing a project and are coincide with the four stages of labour activity as a process. Considering labour as a psychological process by the nature of its inner content, M. Levitov [4] refers it to the category of conscious, goal-oriented actions. It means that the first step in labour is setting a labour task and comprehending it in case it was set by another person (it is the $1^{\text {st }}$ step of project and technological activity). The second one involves choosing means and ways of performing a labour task. It requires discussing, thinking (it is the $2^{\text {nd }}$ step of the project and technological activity). The third step is doing the task (it is the $3^{\text {rd }}$ step of the project and technological activity). The fourth one is checking which implies discussion, correction of mistakes and supplementing (it is the $4^{\text {th }}$ step of the project and technological activity).

Every stage is characterised by a relevant system of students' successive actions while doing a project. A teacher's task, on the one hand, is to organise and provide students learning and development and, on the other hand, to be an equal participant who generates his/her own

\section{REFERENCES}

1. Dyuy, Dzh. (1992). Shkola i obshchestvo [School and society]. Moscow: Rabotnik prosveshcheniya [in Russian].

2. Kobernyk, O. M. (2001). Metodyka orhanizatsii proektno-tekhnolohichnoi diialnosti uchniv na urokakh trudovoho navchannya [Methods of organisation of project-technology activities for students at Design and Technology lessons]. Uman [in Ukrainian].

3. Kobernyk, O. M., Berbets, V. V., Dubova, N. V. (2010). Trudove navchannya $v$ shkoli: proektnotekhnolohichna diialnist. 5-12 klasy [Design and technology lessons at school: project-technology activities for 5 12 forms]. Kharkiv: Osnova [in Ukrainian].

4. Levitov, N. D. (1963). Psikhologiya truda [Labour psychology]. Moscow: Uchpedgiz [in Russian].

5. Serheev, Y. S. (2008) Kak orhanyzovat proektnuyu deyatelnost uchashchykhsya: Praktycheskoe posobye dlya rabotnykov obshcheobrazovatelnykh uchrezhdeniy [Organising project-technology for students. Practical guide for the educators]. Moscow: ARKTY [in Russian].

\section{ЛІТЕРАТУРА}

1.Дьюи Дж. Школа и общество / Джон Дьюи. М.: Работник просвещения, 1992. - 48c.

2. Коберник О. М. Методика організації проектно-технологічної діяльності учнів на уроках трудового навчання / О. М. Коберник, С. М. Ящук. - Умань, 2001. $-80 \mathrm{c}$.

3.Коберник О. М. Трудове навчання в школі: проектно-технологічна діяльність. 5-12 класи / За заг. ред. О. М. Коберника, О. М. Коберник, В. В. Бербец, Н. В. Дубова та ін. -Х.: «Основа», 2010. - 256 с.

4.Левитов Н. Д. Психология труда / Н. Д. Левитов. - М. : Учпедгиз, 1963. - 340 с. ideas, analyses the situation and helps in collecting the material.

\section{Conclusions}

We believe that teachers should obtain practical experience of organising a project activity and mastering design and technologies of skilfulness in their scientific and methodological training in order to learn the methods and be ready to implement a project and technological activity in their work efficiently.

The establishment of training centres at schools with experienced teachers work and relevant resources such as lesson plans workbooks, textbooks can enhance implementing the project method in the educational process.

A significant factor of the efficiency of training future teachers of Design and Technology is their own attitude towards learning and in particular their professional development. It is clear that it is necessary to develop syllabus and methods of learning and to organise the educational process in the first, second and third years so that students should develop their interest in the subjects which provide their professional development.

6. Trudove navchannya 5-9 klasy. Prohrama dlia zahalnoosvitnikh navchalnykh zakladiv [Design and technology lessons for 5-9 forms. Curriculum for general educational institutions]. Retrieved from: http://mon.gov.ua/activity/education/zagalnaserednya/navchalni-programi-5-9 klas-2017.html [in Ukrainian].

7. Yashchuk, S. M. (2003) Vykonannya osnovnykh etapiv proektuvannia na urokakh trudovoho navchannya [Projecting at Technology lessons. Principal stages]. Trudova pidhotovka $v$ zakladakh osvity - Labour training in educational institutions, 2, 13-16 [in Ukrainian]

8. Knoll, M. (2014). Projekt Method. Encyclopedia of Education Theory and Philosophy. (Vol. 2). D. C. Phillips (Ed.). Thousend Oaks, CA: Sage [in English].

9. Robert, T. Howell (2003). The Importance of the Project Method in Technology. Education Journal of Industrial Teacher Education, 3. (Vol. 40) [in English].

5. Сергеев И. С. Как организовать проектную деятельность учащихся: Практическое пособие для работников общеобразовательных учреждений / И. С. Сергеев. - 6-е изд., испр. и доп. - М. : АРКТИ, 2008. -80 c.

6. Трудове навчання 5-9 класи. Програма для загальноосвітніх навчальних закладів. - [Електронний pecypc]. http://mon.gov.ua/activity/education/zagalnaserednya/navchalni-programi-5-9-klas-2017.html

7. Ящук С. М. Виконання основних етапів проектування на уроках трудового навчання / С. М. Ящук // 
Трудова підготовка в закладах освіти. - 2003. - № 2. C. $13-16$.

8. Knoll M. Projekt Method / M. Knoll // Encyclopedia of Education Theory and Philosophy. - Thousend Oaks, CA: Sage 2014. - Vol. 2.
9. Robert T. Howell. The Importance of the Project Method in Technology / T. Robert Howell // Education Journal of Industrial Teacher Education. - 2003. Volume 40. - Number 3. теорії і методики технологічної підготовки, охорони праці та безпеки життєдіяльності, Центральноукрайнський державний педагогічний університет імені Володимира Винниченка, вул. Шевченка, 1, м. Кропивницький, Украӥна

\section{МЕТОД ПРОЕКТІВ НА УРОКАХ ТРУДОВОГО НАВЧАННЯ В УМОВАХ РЕФОРМУВАННЯ НОВОЇ УКРАЇНСЬКОЇ ШКОЛИ}

Реформування сучасної загальної середньої освіти, відображенням якого $є$ Концепція «Нова українська школа», ставить за мету різнобічний розвиток, виховання і соціалізацію особистості, яка усвідомлює себе громадянином України, здатна до життя в суспільстві та до цивілізованої взаємодії з природою, має прагнення до самовдосконалення і навчання протягом життя, готова до свідомого життєвого вибору і самореалізації, трудової діяльності і громадянської активності. Суспільство потребує громадянина, який здатний до самоосвіти та самовдосконалення, вміє критично мислити, опрацьовувати різноманітну інформацію, використовувати набуті знання і вміння для творчого розв'язання проблеми, прагне змінити на краще своє життя і життя своєї країни. Реалії сучасного життя вимагають від технологічної освіти впровадження нових методів, прийомів і технологій навчання, до яких відноситься проектна технологія навчання. Основою проектної технології є розвиток в учнів пізнавальних навичок, критичного мислення, вміння самостійно конструювати свої знання й орієнтуватися в інформаційному просторі, що дає підстави називати їі технологією нового постіндустріального суспільства. Особливої актуальності проблема теоретико-методологічних основ застосування проектної технології в навчанні набуває в зв'язку з прийняттям нової навчальної програми з трудового навчання. Впровадження методу проектів в навчально-трудову діяльність учнів дозволяє оптимізувати навчальний процес, полегшити засвоєння учнями нового матеріалу. У статті розкрито сутність методу проектів, визначено його основні завдання, види $\mathrm{i}$ структуру проектів, які впроваджуються на уроках трудового навчання, детерміновано роль учителя в проектно-технологічній діяльності, подано вимоги, яких слід дотримуватися і вчителеві, і учневі при виборі об'єкта проектування.

Ключові слова: метод проектів, трудове навчання, проектна технологія, проектно-технологічна компетентність, творча діяльність.

Reviewed by Doctor of Pedagogy, prof. S. Yashchuk

Submitted on April, 17, 2017 